\title{
10
}

\section{THE TALIBAN AND THE MODERN HISTORY OF AFGHANISTAN}

\author{
Rob Johnson
}

Since the 1970s, Afghanistan has been a country in conflict. It has often been asserted that violence among Afghans is endemic and this "natural" belligerence, along with the mountainous terrain of the country, accounts for the defeats of successive waves of invaders. ${ }^{1}$ This simplistic interpretation is used to explain why guerrilla resistance in Afghanistan wore down the Soviet Union and forced their withdrawal in 1989 and why the United States and its allies continue to struggle with establishing peace long after their military intervention was officially ended in 2014. The argument is often made that no foreign military force can ever win in Afghanistan, with additional references to the British in the 19th century. This history has led to Afghanistan earning the nickname of the "graveyard of empires."

These simplistic judgments, however, are misleading. The British regarded Afghanistan as a security zone, a region that would be denied to its enemies to protect the landward approaches to its possessions in India and which would be controlled through its rulers rather than permanently occupied. The tactical setbacks the British suffered did not affect their strategic or operational control of the country. Moreover, several empires controlled Afghanistan in similar ways without significant problems-including the Persians and Mughals - by co-opting local Afghan leaders as their intermediaries. Nevertheless, the tendency is to assume that the unsuccessful Soviet experience is the norm.

There have also been romantic ideas that Afghanistan should be returned to its "natural" tribal or medieval state. While seemingly fossilized in parts of the country, Afghanistan's social structure and culture are changing rapidly. Young Afghans refuse to allow their country to remain in the past. The majority of Afghans are eager for change, looking for new opportunities, and interested in the future. They do not embrace a "medieval" conception of their country, even where they accept the values of their faith and their traditions. ${ }^{2}$

While traditions and culture thrive among impoverished populations in much of rural Afghanistan, a brief tour around the major cities reveals just how much the country has changed since $2001 .{ }^{3}$ Afghanistan is making the important transition from a hierarchical and agrarian society to a modern, bureaucratic state, but state building is never a smooth process, and the conflicts that have lasted for decades have distorted the country's development. Afghanistan failed to achieve its transformation in the 1980s and 1990s, while insurgency has stunted and arrested the development of the country for an additional two decades.

Afghan citizens have had to face the reality of marauding banditry by gunmen and by undisciplined, corrupt police, as well as the intimidation of narco-gangsters. Afghans are caught in a struggle for survival where guns and money replace clan allegiances and codes of honor. Yet this has also been a conflict about the form that a new Afghanistan should take: one ideological and atavistic, while the other is based on 
economic modernization. The unfortunate consequences of the conflict between these world views is the survival of patronage and an unbridled search for profit and power, as well as considerable violence.

This chapter identifies the challenges facing Afghanistan, with a particular emphasis on the post-2001 period. It focuses on the key themes of the conflict, specifically insurgency, terrorism, narcotics, governance, and security. It also includes an analysis of the Taliban, the organization whose association with international terrorists provoked Western military intervention and has driven Afghanistan's insurgency ever since.

\section{From the anti-Soviet insurgency to the civil war: 1978-1996}

The Afghanistan insurgency of the early 21st century is the legacy of a civil war that began in 1978 . When communists seized power in Kabul that year, the coercion and violence that accompanied their unpopular social and economic reforms sparked resistance. The communists' purges and factional fighting provoked open revolt, and this in turn prompted Soviet military intervention a year and a half later. The Soviets did not consider the possibility of a growing insurgency, and Moscow struggled to comprehend the conflict. ${ }^{4}$

To halt what appeared to be Soviet expansionism, the United States, Pakistan, and the Gulf states intervened indirectly by supporting the mujahidin resistance fighters. ${ }^{5}$ As the fighting intensified, millions of Afghans became refugees, most seeking sanctuary in Pakistan's tribal belt and the borderlands of Iran. Crucially, the Pakistan border area provided a safe haven for the insurgents and their families from the 1980s onward. Pakistani tribal leaders and authorities exploited this situation for their own interests, seeking to control the government in Kabul and prevent it from falling under the influence of its rival, India, or any faction it considered a threat. ${ }^{6}$

The fighting proved deadly to the population, with millions killed during the war. ${ }^{7}$ Insurgents made extensive use of mines and improvised explosive devices, and the communists retaliated with extreme measures. ${ }^{8}$ Both adversaries proved especially deadly to a people largely dependent on agriculture and confined to limited areas of settlement and routes because of the mountainous terrain.

When the Soviets withdrew in 1989, optimism reigned. Observers hoped that the Afghans could settle their differences and rebuild the country. Such hopes, unfortunately, were short lived. Instead, the mujahidin resistance factions fought each other, and the central government collapsed when funding from the Soviet Union ended abruptly in 1991. ${ }^{9}$ State institutions withered and virtually disappeared. Gunmen and warlord-led clans battled it out on Kabul's streets, reducing the city to ruins, while roadside robberies and taxation at the muzzle of an assault rifle became the norm. ${ }^{10}$

After two years of chaos, the Taliban - largely Pashtun southerners who attracted Pakistan's supportbegan to overrun factions around Kandahar. The Taliban then seized Herat before bombarding Kabul with artillery and launching rockets into the city center. ${ }^{11}$ Pakistan's military backed the Taliban because Islamabad wanted a compliant, pro-Pakistan authority in Kabul. ${ }^{12}$ Pakistan's Inter-Services Intelligence, its main intelligence agency, swung its full weight behind the Taliban and supported its assault on the capital in September $1996 .{ }^{13}$ Still divided, the other factions abandoned Kabul in the face of the Taliban onslaught. ${ }^{14}$

Afghans in the south initially welcomed this austere, puritanical, and militant sect because it promised to end the civil war. ${ }^{15}$ While the ethnic composition of Afghanistan is complex, the Pashtun population, broadly observing Sunni and conservative Islam, dominates the south and east, with significant enclaves in the northwest (Badgheis Province) and northeast (Kunduz Province)..$^{16}$ The northern and central populations of Afghans are a mixture of Sunni Uzbek, Tajik, Shia Muslim Hazarajat, and other minorities, each representing waves of historic migration and settlement. ${ }^{17}$

Afghans in regions with sectarian or ethnic differences to the Taliban reacted in horror to the group's ultra-conservative and coercive policies. Northern communities resisted from the outset because the Taliban exhibited intolerance and brutality toward them. ${ }^{18}$ In time, the Taliban subjected all Afghans, not just northerners, to draconian restrictions, executions based on spurious evidence, and random torture. ${ }^{19}$ Many 
suspected that such untypical behavior must be foreign inspired, from the more extreme Deobandi tradition of Pakistani madrasas (religious schools) or from purist Arabs who looked down on bucolic Afghan culture. ${ }^{20}$

In theory, the Taliban was a militaristic organization eager to turn the clock back to an idealized version of Islamic society. ${ }^{21}$ In practice, however, many Taliban recruits were disaffected and angry young men, strengthened by veterans of the war against the Soviets, including the so-called "Arab Afghans"-foreign fighters from across the Middle East, Africa, and Europe who had fought alongside the Afghan mujahidin. ${ }^{22}$

Repudiating politics, the Taliban's leader, Mullah Muhammad Omar, referred to himself as Amir alMomineen (leader of the faithful) and sought exclusive power legitimized as a "divine right." ${ }^{23}$ Mullah Omar employed the props and rhetoric of Islam, impressing his followers with a dignified piety. ${ }^{24}$ In reality, he ruled with an oligarchy of friends and allies.

The Taliban made use of their Pakistani intelligence and military contacts, but they also relied on the support of drug barons and provincial governments. ${ }^{25}$ For recruits and influence beyond the country, they accessed networks of Deobandi madrasas in Pakistan. ${ }^{26}$ Taliban fighters found themselves among idealistic comrades who shared radical ideas and were fed a heady cocktail of religious dogmatism and militant doctrine.

Despite their righteousness and self-confidence, the Taliban never fully controlled Afghanistan. Groups gradually united against the Taliban under the banner of the National Islamic United Front for the Salvation of Afghanistan, more commonly known as the Northern Alliance. ${ }^{27}$ The northerners' resistance drove the Taliban to greater brutality against the Afghan people.

In August 1998, the Taliban overran Mazar-i-Sharif and massacred large numbers of civilians, mainly Shia Hazaras. ${ }^{28}$ Survivors state that the killing went on for three days, led by foreign Taliban fighters under the direction of Mullah Omar's loyal lieutenant, Mullah Abdul Manan Niazi. The Taliban reportedly killed people in unimaginable ways, including asphyxiation by locking people in metal containers in the sun. Firing squads toured the streets, and decrees forbade the inhabitants from moving or burying the bodies. Eyewitnesses spoke of dogs tearing at corpses. ${ }^{29}$

In the northern province of Badakhshan, the anti-Taliban forces of Ahmad Shah Massoud were the most successful in defying Mullah Omar's attempts to coerce all Afghans into submission. His resistance inspired a generation. Although Massoud was killed in 2001, he has been venerated ever since. ${ }^{30}$

The Taliban's primary objective was "security." They claimed to be asserting Sharia (Islamic law) and restricted private and public life under the auspices of protecting the Afghan people. They expressed a desire to continue the jihad until there were no opponents left, and they aimed for a "strong" Afghanistan. The Taliban made sure their laws were strictly enforced, often by a "religious police," the Amr bil-Maroof wa Nahi An il-Mukir (Department for the Promotion of Virtue and Suppression of Vice). ${ }^{31}$ Those who fell foul of the religious police in Kabul could be stoned to death or executed publicly by firing squad. ${ }^{32}$

The Taliban targeted any element of liberal culture: they banned television and only tolerated radio as a means of propaganda, prayers, and the broadcast of new decrees. They outlawed music, dancing, playing games, flying kites, drumming, and all visual representations of animals or people. ${ }^{33}$ On March 10, 2001, the Taliban destroyed 1,500-year-old Bamiyan Buddha statues. ${ }^{34}$

International opinion, already angered by the cultural destruction, soon focused on the Taliban mistreatment of women. The Taliban argued the "face of a woman is a source of corruption for men." ${ }^{35}$ Women often had to forego medical treatment and were denied education, forced into marriages, and prevented from traveling. ${ }^{36}$ They were rendered invisible with decrees on dress and kept out of public view. Denied employment, many war widows were left destitute. ${ }^{37}$

Under the Taliban, Afghanistan became a springboard for al-Qaida's terrorist operations. ${ }^{38}$ On August 7, 1998, al-Qaida operatives detonated suicide car bombs outside the U.S. Embassies in Kenya and Tanzania. ${ }^{39}$ The coordinated bombings killed 224 people. The United States retaliated by launching cruise missiles 
against al-Qaida camps in Afghanistan and Sudan. ${ }^{40}$ Washington froze Taliban assets in the United States, and the United Nations followed with sanctions, demanding that al-Qaida chief Usama bin Ladin be handed over to U.S. custody. In December 2000, the United Nations imposed military sanctions, increasing the pressure on the Taliban. ${ }^{41}$ Meanwhile, al-Qaida, harbored by the Taliban, issued statements advocating "global jihad."

\section{9/11 and the fall of the Taliban}

The Taliban's decision to allow al-Qaida to base itself in the country and mount the 9/11 attacks on the United States marked their greatest strategic error. After 9/11, the U.S. military retaliated. Overwhelming American air power guided by Special Operations Forces, working alongside the Northern Alliance, defeated the Taliban in a matter of weeks. After what served effectively as an ultimatum, President Pervez Musharraf of Pakistan declared himself in favor of U.S.-led action in Afghanistan. Pakistan's policy of creating a compliant state on its western border had failed spectacularly, but their national interest in creating a pro-Pakistani state would not disappear entirely.

The U.S.-led coalition deployed thousands of bombs and missiles in the space of a few weeks. Even seasoned Taliban veterans broke under the intensity of the attacks. Many fighters later explained that they could not even see the aircraft that attacked them. ${ }^{42}$ The Taliban especially feared the 15,000-pound BLU82 "Daisy Cutter," although it was only dropped on four occasions. ${ }^{43}$ The CBU-103 "Combined Effects Munitions," colloquially known as a "cluster bomb," were also highly effective, although the debris of unexploded ordnance attracted criticism. ${ }^{44}$

Despite fears of indiscriminate bombing, 6,700 of the weapons used were precision-guided. Special Operations Forces could lay down carpets of explosions a few hundred yards in front of their own positions without inflicting civilian or friendly casualties.

The Taliban collapsed swiftly because they did not have much legitimacy to govern. ${ }^{45}$ They had demonstrated that they were just as ruthless and uncompromising as previous regimes, all of which had managed to alienate substantial sections of the Afghan people. ${ }^{46}$ The Taliban were forced to depend on their original Pashtun heartland in the south and east, cut deals with other groups in the facilitation of narcotics, and then play on the idea of a foreign occupation or corrupt government to garner support. ${ }^{47}$

When Mullah Omar fled Kandahar, he spoke in terms of an approaching apocalypse, but this only exposed the fact that the Taliban had little to offer except violence and coercion. ${ }^{48}$ Under the Taliban, the country had remained in ruins, and its people lived in intolerable conditions, held in check only by repression. Like the Islamic State in the period of 2014-2017, the promises of an idealized Muslim polity turned out to be no more than political extremism, torture, summary execution, and, for its adherents, a cult of martyrdom.

The Bonn Conference of October 3, 2001, marked the beginning of a long and difficult process of reconstruction. Six neighboring countries plus the United States and Russia (known as the "Six plus Two") agreed that Afghanistan should enjoy a multi-ethnic, freely elected government. Nevertheless, at the subsequent meeting of Afghans that December, important continuity figures were not present: warlord Abdul Rashid Dostum; Taliban leaders; and the former king, Zahir Shah. Even so, participants agreed on a "road map" for peace starting with the formation of an interim administration. An emergency loya jirga (Grand Council) was created. ${ }^{49}$

In addition, an international peacekeeping force, the International Security Assistance Force (ISAF), would be deployed. ISAF had the task of restoring confidence in Kabul and protecting the leaders of the new administration from terrorist groups. ${ }^{50}$ Meanwhile, U.S. and allied Special Operations Forces continued to hunt down al-Qaida operatives. ${ }^{51}$

Most encouraging about the peace process were the early steps taken to hand over authority to the Afghans. The first priority was security, so the presence of ISAF was crucial. There was no question of 
permanent occupation, nor was there an opportunity, as had occurred in 1989, for Pakistan to intervene in Afghan politics for its own ends. ISAF's presence meant warlords could not resume their violent campaigns.

Expectations, however, proved impossible to fulfill, and it did not take long for criticisms of the Western effort to develop. Afghans needed to feel the effects of material prosperity as a peace dividend, and they looked eagerly toward the wealth of the West for assistance. Unfortunately, Afghan hopes for immediate recovery and development could not be met, and the U.S. administration did not commit to "nationbuilding." There was certainly an expectation in the United Nations that reconstruction of Afghanistan would take place, but the American military priority was the pursuit and defeat of al-Qaida.

Specialists also pointed out that Afghanistan's “construction," rather than "re-construction," would actually take decades. ${ }^{52}$ The overriding problem was that lawless armed groups held Afghanistan at their mercy, and too few troops had been dedicated for the security tasks that had emerged after 2001.

In 2006, a steady stream of American and NATO troops arrived, taking over responsibility for the eastern and southern provinces. At its peak, Western combat troops across the country numbered nearly 130,000, with especially heavy concentrations in the south and east where the Taliban had the strongest presence.$^{53}$ Special Operations Forces augmented conventional troops, who were all supported by complete control of the air through both manned and unmanned armed aircraft.

There were evident problems with the initial strategy for Afghanistan. Afghans complained about a lack of human security, a precarious economy, vulnerable agricultural yields, and corrupt officials; Afghans often found those issues more pressing than the Taliban threat. ${ }^{54}$ Yet United Nations and military officials, lacking the experience of development work but drafted in to cover the absence of government advisors and non-governmental organizations, took a patronizing approach and failed to engage Afghans at a local level..$^{55}$

Contract workers went unchecked, and a practice of sub-contracting and exorbitant costs reached epidemic proportions. ${ }^{56}$ The result was patchy development work, often of a low standard, with investment in buildings and short-term projects rather than people.

The lack of qualified police officers further exacerbated the weak national Afghan criminal justice system. ${ }^{57}$ An auxiliary police, created from militiamen, proved corrupt and too small to be effective. The police training program in Kabul, operated by Germany, was too slow and unable to furnish sufficient numbers to meet demands beyond Kabul..$^{58}$

There were significant rifts in the approaches of NATO members who participated in ISAF, particularly over their mission, rules of engagement, and attitude toward risk. ${ }^{59}$ Locals who might have provided security personnel and development workers, in the style of the traditions of village arbakai (militias), were disarmed because of a fear of private armies. ${ }^{60}$ From a legal point of view, there were disputes about whether Sharia should take precedence over secular law, and there were protests from Western governments who wanted to see Afghanistan built more in their own image. ${ }^{61}$

Reconciliation was also a contested area. The proximity of the Taliban to al-Qaida in ideological terms meant that Western states had no appetite for talks with the Taliban. Conversely, the Afghan government decided against criminalizing the Taliban in the hopes of a rapprochement and was determined to remain in control of all negotiations, even if that meant derailing any foreign initiatives in the short term. ${ }^{62}$ Any suggestion of power sharing between Pashtuns and non-Pashtuns seemed to anger or disappoint every faction.

There were some aspects of the Western-led stabilization effort in Afghanistan that moved in the right direction, needing only time, manpower, and money to sustain them. Unfortunately, the diversion of resources to Iraq in 2003 checked progress in security and reconstruction at a critical time. Nevertheless, the recruitment of a new Afghan security force proved essential, and the Afghan National Army began to grow from 2001 and soon became an evident source of pride..$^{63}$ Yet the strategic priority of the Western powers was to deny Afghanistan as a base for further operations by al-Qaida and its allies, and that meant less interest in developing Afghanistan as a whole. ${ }^{64}$ 


\section{The Taliban resurgence}

After the U.S.-led invasion in 2001, the Taliban used Pakistan's border area as a relative safe haven. The Taliban strategy sought to recreate an emirate, win over more Afghans to their cause, impose Sharia, and maintain Pashtun supremacy. ${ }^{65}$ Their method focused on undermining Western efforts, using force to demoralize and weaken Western forces to keep resistance alive, sustain the idea of a liberation struggle, and wage a war of "national" defense. Their tactics were not just military-style attacks but the intimidation and murder of Afghans. ${ }^{66}$

In 2006, a blend of al-Qaida and Taliban forces re-emerged, conducting a campaign of insurgency and terrorism. Their objective was to "discipline" the Afghan people, to co-opt and recruit local fighters, and to wage unrelenting hit-and-run warfare to make Afghanistan ungovernable. They sought to pressure the United States and its NATO allies to leave the country, believing they could do the same to the Americans as they had to the Soviet Union. ${ }^{67}$

One rural interviewee gave a vivid impression of the low-key character of intimidation by insurgents:

One night around midnight someone knocked on the door of our house. We were terrified, fearing that the police had come back to arrest me or my brother once again. But when we opened the door, it was one of my father's former students. He had a Kalashnikov on his shoulder and was a Taliban sub-commander already. The two other Taliban he was with also carried AKs and had several hand grenades attached to their belts. This was my first encounter with the Taliban since the defeat. We invited them to spend the night. Early the next morning I accompanied them to the mosque. My father's former student read out the names of those he accused of having betrayed Islam by following [Afghan President Hamid] Karzai and the infidels. He warned them to cease all contact and to quit any job they may have had with the government or the Americans. He ended by saying he would return in one week. ${ }^{68}$

Each year, the insurgents would attempt to build up their forces in the late winter and early spring, and conduct a "fighting season" of attacks from March to October. This would be followed by a lull as they attempted to regenerate forces and restore command and control. Weapons and ammunition passed along "main supply routes," many of which were traditional smuggling trails.

The Taliban have had diverse sources of income, ranging from donations from wealthy Gulf businessmen, ideologues in Pakistan, extortion from haulage firms taking goods into Afghanistan, racketeering within Afghanistan, and roadside intimidation. ${ }^{69}$ The Taliban invests in security in local areas, providing for the safe passage of goods and extracting a fee. This system allows them to generate more revenue while expanding their influence, building relationships, and dominating the lives of Afghans at a local level. ${ }^{70}$

The Taliban also derived significant sums of money from narcotics. Notoriously, Afghanistan produces over $90 \%$ of the world's opium. ${ }^{71}$ Refined into heroin, a portion remains in the region to supply a growing regional addict population, especially in Iran and Afghanistan, and the rest is exported, primarily to Western Europe via Africa or Central Asia. For farmers, opium is

a miracle crop. . . [maturing] quickly, allowing double cropping . . . it is more weather-resistant than wheat, is easy to store, transport, and sell. . [and] can easily be stored . . . as a form of savings in a country that until recently was wracked by inflation. ${ }^{72}$

The Taliban recognized the importance of opium to Afghan farmers, and they were careful to frame support for the trade against government eradication and corruption. They offered financial backing to those whose fields were being eradicated in exchange for support against the government, and they assisted 
in the guarantee of production by ensuring that payments were delivered to the farmers even before the crop had been harvested. ${ }^{73}$ By providing security and safe passage, they made the opium trade viable.

Crucially, the opium trade has produced national and international networks of production, refinement, and export that have changed social relationships within Afghanistan. It offers a powerful few enormous influence, enabling them to dispense with traditional forms of governance and to buy off interfering government officials. The insurgents, criminal groups, and government remain locked in a struggle for this critical part of the Afghan economic ecosystem. But the opium trade also distorted the Taliban itself, setting up resentment between southern Pashtuns and the central "Quetta Shura" headquarters. ${ }^{74}$

When under significant pressure from ISAF or the Afghan security forces, the Taliban and other insurgent groups, like the Haqqani network on the Pakistan border, resorted to more significant acts of terrorism, often in urban areas. ${ }^{75}$ Large scale vehicle-borne improvised explosive devices or suicide raids by small groups of men were designed to demoralize the Afghan government and persuade Western coalition forces to withdraw. ${ }^{76}$ The Taliban rejoiced at the announcement in 2009 that the West would begin its drawdown and transition, and they believed they had "brought down the elephant." Their objective was to finish the process with a sustained campaign of violence.

In 2009, General Stanley McChrystal, the ISAF commander, announced a modification to the West's strategy in Afghanistan. ${ }^{77}$ The objective remained the defeat of al-Qaida and the stabilization of the country under the leadership of the government in Kabul, but McChrystal argued that the method was of vital importance. McChrystal believed that Afghans needed to play a bigger role.

As part of this strategy, McChrystal and other military commanders convinced the White House that they needed to "surge" more U.S. troops into Afghanistan. The Obama administration authorized 33,000 more troops, which would be used to assist the expansion of the Afghan National Security Forces, hold critical areas of the south against Taliban advances, and boost support to local government structures. ${ }^{78}$

McChrystal immediately demanded a rapid increase in numbers of Afghan National Security Forces personnel. He urged the reprioritization of resources to signal the West's long-term commitment to Afghanistan. McChrystal also made clear, somewhat controversially, that he intended to protect the Afghan population not only from the Taliban but also from the corrupt and coercive elements of the Afghan government. In short, he wanted to implement a classic counterinsurgency doctrine to win the "hearts and minds" of the population and to drive a wedge between the people and the insurgents. ${ }^{79}$

The relatively small scale of coalition manpower available, especially compared with concurrent operations in Iraq, meant that there was a greater incidence of airstrikes to protect units. Those planning coalition military operations in Afghanistan showed an awareness of the dangers of reliance on air powerespecially the accidental and adverse consequences of killing civilians. ${ }^{80}$ The intention was to prevent civilian casualties altogether, but while this aim went further than the strict laws of international armed conflict, in practice, it was not achieved.

Many factors prevented its realization, such as poor intelligence and target selection, the proximity of military targets and civilians, weapons malfunctions, and periodic misunderstandings between ground and air forces ${ }^{81}$ President Karzai, whose authority had been diminishing, felt compelled to increase demands on the coalition, criticizing airstrikes and insisting on terminating the arrests of Taliban suspects and their supporters in night raids. ${ }^{82}$

ISAF wanted to tackle the insecurity of the population by neutralizing the insurgents and reassuring the Afghan people with an overt military presence. The insurgents, however, were determined to maintain resistance; terrorist attacks in the cities were a means to divert public attention whenever the insurgents came under pressure in rural areas. ${ }^{83}$ Taliban attacks on aid organizations also increased, as the Taliban believed that aid groups furthered the government's interests. The Taliban attacks forced some aid agencies to leave.

ISAF's answer was to develop more effective Afghan National Security Forces. Despite predictions that service would be unpopular, a large volunteer army was created. There were initially criticisms that Tajik 
Afghans retained most positions of command despite provincial quotas that allowed for ethnic groups to be represented proportionally, but the dynamic was in part a legacy of the Northern Alliance victory in 2001. While Pashtuns were encouraged to enlist, literacy and competency levels were lower among southerners, even by Afghan national standards. In some cases, Pashtun recruits feared Tajik-dominated forces, and promotion appeared to be influenced by patronage networks more than merit.

The Afghan National Security Forces had a variety of other problems. Some soldiers sold their equipment for personal profit; those absent without leave rose in number but went unpunished; and, despite screenings, there were concerns about narcotics abuse. ${ }^{84}$ But there were positive developments as well. Abuse against civilians declined rapidly as training improved, a new pay system reduced ghost pay-rolling, and rumors of the killing of Taliban prisoners declined as the criminal justice system improved after $2010{ }^{85}$ Recruit training was extended, and contracts lasted three years to improve service conditions. ${ }^{86}$

Inevitably, there were still concerns that insurgents might intimidate, torture, or kill the families of Afghan National Security Force members. ${ }^{87}$ Initially, there was little troop rotation out of the danger zones, the best units were often over-worked, and casualties ran as high as $15 \%$. The most significant ongoing challenge, however, was leadership. ${ }^{88}$

Western mentors embedded with Afghan troops to assist in the development of experienced junior commanders. ${ }^{89}$ This proved an excellent interim measure, although there were complaints on both sides about expectations. ${ }^{90}$ There were several "green-on-blue" incidents where Afghan soldiers, or disguised insurgents, turned their guns on their coalition mentors. ${ }^{91}$ Yet as larger Afghan units formed, and specialist leadership training developed, advisors replaced the embedded teams, allowing Afghan formations to operate independently.

There were, as one would expect for a new army, limitations in their capabilities, especially in intelligence, logistics, vehicle maintenance, air mobility, heavy weapons, and transport. By 2010, however, the Afghan military took control over more areas of Afghanistan, allowing the establishment of political control. The Afghan government set up an Afghan Air Corps (and later an air force) and also established pay facilities, training institutions, and a medical evacuation chain. ${ }^{92}$

In insurgencies, there are always individuals who exploit the presence of military forces for their own ends. Some provincial groups and leaders tried to acquire U.S. or foreign development funding while keeping open links with the insurgents. In Kunar Province in 2008, one group of local leaders manipulated both insurgents and ISAF by inviting fighters to "defend" their valley against foreigners, knowing that Western troops would clear the area and then commence development work as part of the "shape, clear, hold and build" tactic. Once the insurgents had served their purpose, the locals drove them out and embraced the construction projects but expressed the hope that the foreigners would also leave. ${ }^{93}$

Local security forces, or irregular forces, were considered vital to building local governance because they provided the link between local leaders, local justice, and the national government. Local security forces could be kept accountable to their own communities while being licensed by the central authorities, which could be considered a form of social contract. ${ }^{94}$ Although local forces were distrusted because of the fear of large, unregulated militias, the fact was that everything in Afghanistan required tailoring to local needs. ${ }^{95}$ Throughout the campaign, the West's aim was consistent in wanting to improve security, which meant, ultimately, getting Afghans into a position where they could sustain themselves.

The conflict in Afghanistan would have been far easier to resolve had it not been for the activities across its borders. Iranian leaders perceived that they had been encircled by the United States with its troops in Iraq and Afghanistan. Iranian intelligence made every effort to maintain links to the Afghan government, to the leaders of Herat, and to some insurgent groups. Nevertheless, Iran suffered the effects of Afghan opium trafficking, and Tehran grew concerned about the assertiveness of Baloch insurgents within its borders. ${ }^{96}$

Pakistan had its own agenda, pursuing a form of hybrid warfare against Western interests while denying any involvement in the conflict. ${ }^{97}$ Pakistan's main goal was preventing Indian influence in Kabul, but 
it also wished to persuade the United States to abandon the Afghans to foster its own relationship with the Afghan Pashtun population, a group it regards as a potential paramilitary asset against India and other rivals. ${ }^{98}$ Afghanistan's various insurgent groups could cross the "Durand Line" that demarcates Afghanistan and Pakistan and find sanctuary in Pakistan's Federally Administered Tribal Areas, where they could purchase weapons and ammunition, recruit refugees, indoctrinate trainees, select suicide bombers, rehearse operations, arrange command appointments, rest their fighters, and plan missions.

The United States recognized the problem of operating across a sovereign border, and in time they orchestrated a campaign of drone strikes. Pakistan cooperated when it suited their interests, but it protected certain militant groups. The greatest humiliation for Pakistan was the discovery of Bin Ladin in a compound in Abbottabad, well inside Pakistan's borders. Knowing that Pakistan would not cooperate, the United States launched a daring and successful Special Operations Forces mission to kill the al-Qaida leader. Pakistan retaliated by closing ground lines of communication across its borders and withdrawing its "support," but it had been exposed as an unreliable ally.9

The death of Bin Ladin had in effect ended the raison d'être of the U.S. intervention in Afghanistan. Al-Qaida was scattered, many of its operatives had been killed, Afghanistan was a sufficiently stable if financially dependent nation-state, and there was no strategic interest in fighting the Taliban in perpetuity.

After the end of Western combat operations in 2014-the extra troops from the "surge" had left in 2012 - the insurgents stepped up their attacks and inflicted significant losses on Afghan security forces for two years. Then, in late 2014, a new threat emerged in the eastern province of Nangarhar, inspired by the Islamic State movement in Syria. Known as the "Vilayet Khorasan," or Islamic State Khorasan, these fighters emulated the tactics and brutalities of the Islamic State, murdering their opponents and terrorizing the population. The United States led the effort to neutralize this emerging threat while being careful not to permit itself to be drawn into yet another "large footprint." The emphasis was on enabling the Afghan security forces. ${ }^{100}$

After a series of "spectacular" mass casualty terrorist attacks - including the massacre of patients and staff in a Kabul maternity unit in May 2020, murders of police officers, attacks on funeral gatherings, and other acts of depraved violence - the Islamic State Khorasan movement suffered a steady and mounting stream of casualties. These terrorist attacks appeared to attract radical recruits, but the extreme violence had already alienated the Afghan and Pakistani Taliban, al-Qaida, and the Haqqani network. There were also unconfirmed reports of pitched battles between the Taliban and Islamic State Khorasan.

The U.S. announcement in 2017 that it would sustain Afghanistan's funding and support for at least four more years dealt a serious blow to the Taliban and other militant groups in Afghanistan. The Taliban made a full U.S. withdrawal a condition for negotiations to end the conflict. Yet the Taliban also knew that they had not inspired a nationwide resistance, as had been the case against the Soviets. In some southern areas, the Pashtun population resented the Taliban insurgency, especially when terrorists targeted much-needed schools and infrastructure.

This eventually compelled the Taliban to reverse its policy against the education of girls. ${ }^{101}$ None of the urban areas had fallen, and even Taliban attempts to wrest control had been temporary, lasting only a few days. The Americans seemed resolute in their support to the Afghan government, and the country continued its faltering progress toward statehood.

As a result of leadership quarrels in the Taliban, the Haqqani network has emerged as the more effective adversary of the Afghan government. ${ }^{102}$ The Haqqanis draw their lineage from across the AfghanistanPakistan border area, and, with the backing of the Pakistani intelligence services, they proved a useful tool for deflecting militancy from North Waziristan in Pakistan's Federally Administered Tribal Areas into Afghanistan. ${ }^{103}$ For Pakistan, the cohesion of the Haqqanis made them an attractive partner compared with the larger but more factional Taliban.

When the leadership of the Taliban became divided in 2017-2018, Sirajuddin Haqqani, the leader of the Haqqani network, offered an effective alternative movement to weaken the government of Afghanistan. 
Hostage-taking became a useful method to deter drone strikes, while terrorist attacks in Kabul were the means to maintain pressure on the Afghan government and tie down its security personnel. While Islamic State Khorasan and the Taliban have the higher profile, it is the Haqqani network that is likely to have the most lasting influence in Afghanistan's conflict going forward, particularly if Islamabad believes it is the most worthy of its support.

\section{Conclusion}

Afghanistan is a case study of the consequences of both state collapse and uninhibited state power. The process that began with the communist coup of 1978 resulted in the gradual erosion of the Afghan state. Those who propagated ever more radical solutions were, like so many revolutionary zealots, consumed by the forces they had unleashed. Without public support, radicals were forced to turn to terror to enforce their new utopia, and the result was brutality, coercion, atrocities, and failure.

The Taliban, backed by their external allies, are convinced of the righteousness of their ideology, but they have perpetrated the very crimes they claimed to have come to eradicate. While the Islamists believed that they had to destroy the Western presence and Western values, these same values proved essential requirements for social groups to coexist and are shared by both Western and Islamic societies.

Since 2001, despite all the doubts and commitments the West faced, the insurgents failed to overrun or dislodge U.S. forces as they expected. Their major offensives in the south and east from 2006 to 2014 were all defeated militarily. They failed to overturn the Afghan government after the drawdown of Western forces. They failed to prevent elections or the people from voting. Politically, they remained outside the mainstream processes.

After 2014, there was increasing factionalism among insurgent groups in Afghanistan. There was some suggestion that insurgent field commanders would rather be free of the constraints imposed by the command councils based in Pakistan. It is also clear, however, that the Deobandi and Wahhabi doctrines that have sustained their motivation have drawn closer together, and many Taliban fighters now identify with a pan-Islamic ideology, not just a Pashtun-Afghan one.

The peace talks that were supposed to end the conflict in Afghanistan have suffered a number of false starts. ${ }^{104}$ The Karzai administration often accused the United States and its allies of trying to settle a deal that would not be in Kabul's interests. American officials often expressed concern about with whom they could negotiate and whether the representatives who came forward were, in fact, the "authentic voice" of the Taliban. In 2018, however, the Taliban "office" in Qatar seemed to be more serious about a peace process.

On February 29, 2020, the Trump administration concluded a preliminary peace agreement with the Taliban, offering that American forces would withdraw from Afghanistan over a 14-month period if the Taliban ended their campaign of violence. ${ }^{105}$ But the Ashraf Ghani administration rejected a set of proposals that accompanied the deal, whereby there would be a release of Taliban prisoners. Likewise, the Taliban quickly added that their promise was to "reduce violence" for a period of seven days and was in no way intended to be lasting. Thus, it seems that the Taliban intends to continue its war against the Kabul government.

\section{Notes}

1 Keith Stanski, “'So These Folks Are Aggressive': An Orientalist Reading of 'Afghan Warlords', Security Dialogue 40, no. 73 (2009): 73-94.

2 Thomas Barfield, “Is Afghanistan 'Medieval'?” Foreign Policy, June 2, 2010, https://foreignpolicy.com/2010/06/02/ is-afghanistan-medieval-2/.

3 M. Nazif Shahrani, "The Future of the State and the Structure of Community Governance," in Fundamentalism Reborn? Afghanistan and the Taliban, ed. William Maley (London: Hurst, 1998). 
4 Artemy M. Kalinovskii, "A Long Goodbye: The Politics and Diplomacy of the Soviet Withdrawal From Afghanistan, 1980-1992" (thesis, London School of Economics, 2009).

5 Edward Giradet, Afghanistan: The Soviet War (London: Taylor \& Francis, 1985).

6 Seth G. Jones, The Insurgent Sanctuary in Pakistan (Washington, DC: Center for Strategic and International Studies, 2018).

7 Alexander Lyakhovski, Tragedia i doblest Afgana (Moscow: Éksmo, 2009), 1,018; Rodric Braithwaite, Afgantsy: The Russians in Afghanistan, 1979-89 (London: Profile Books, 2012).

8 Giradet described Soviet tactics as inducing a migratory genocide by extensive bombing and reducing areas to rubble. See also Braithwaite, Afgantsy.

9 Ahmed Rashid, Taliban (New Haven: Yale University Press, 2001).

10 William Maley, The Afghanistan Wars, 2nd ed. (New York: Palgrave Macmillan, 2009).

11 Ibid.

12 Gilles Dorronsoro, The Taliban's Winning Strategy in Afghanistan (Washington, DC: Carnegie Endowment for International Peace, 2009).

13 Matt Waldman, The Sun in the Sky: The Relationship Between Pakistan's ISI and Afghan Insurgents (London: Crisis States Research Centre, 2010).

14 "Taliban Poised to Overrun Afghan Capital," Guardian, September 26, 1996, www.theguardian.com/theguardian/ 1996/sep/26/fromthearchive.

15 There was a long tradition of resistance to the authority of the capital. See David Edwards, "Pretexts of Rebellion: The Cultural Origins of Pakhtun Resistance to the Afghan State" (PhD diss., University of Michigan, 1986).

16 For more details on Afghanistan's historical ethnic groups, see Henry Walter Bellew, The Races of Afghanistan: Being a Brief Account of the Principal Nations Inhabiting That Country (Calcutta: Thacker and Spink, 1880).

17 Katharine Adeney, "Constitutional Design and the Political Salience of 'Community' Identity in Afghanistan," Asian Survey 48, no. 4 (2008): 535-557.

18 Neamatollah Nojumi, The Rise of the Taliban in Afghanistan (New York: Palgrave Macmillan, 2002); Kamal Matinuddin, The Taliban Phenomenon: Afghanistan, 1994-1997 (New York: Oxford University Press, 1999).

19 James Fergusson, Taliban (London: Bantam Press, 2010).

20 Barnett R. Rubin, The Fragmentation of Afghanistan: State Formation and Collapse in the International System (New Haven: Yale University Press, 2002).

21 Abdul Salam Zaeff, My Life With the Taliban (London: Hurst, 2011).

22 Mohammed M. Hafez, "Jihad After Iraq: Lessons From the Arab Afghans Phenomenon," CTC Sentinel 1, no. 4 (2008).

23 Michael Semple, Rhetoric, Ideology, and Organizational Structure of the Taliban Movement (Washington, DC: U.S. Institute of Peace, 2014).

24 Zaeff, My Life With the Taliban.

25 See, for example, Rob Johnson, "Managing Helmand From Bost to Bastion," International Area Studies Review 15, no. 3 (2012): 279-300.

26 Zaeff, My Life With the Taliban; Nojumi, The Rise of the Taliban, 154, 180 and 189.

27 Rob Johnson, The Afghan Way of War (New York: Oxford University Press, 2012), 256.

28 Kenneth J. Cooper, “Taliban Massacre Based on Ethnicity," Washington Post, November 28, 1998, www.washington post.com/archive/politics/1998/11/28/taliban-massacre-based-on-ethnicity/efe15f81-abed-4e57-96f1-046cc $59 \mathrm{~d} 1 \mathrm{~d} 48 /$.

29 Maley, The Afghanistan Wars, 230.

30 Quil Lawrence, "In Afghanistan, Assessing a Rebel Leader's Legacy," National Public Radio, September 9, 2011, www.npr.org/2011/09/09/140333732/in-afghanistan-assessing-a-rebel-leaders-legacy.

31 John F. Burns, "Stoning of Afghan Adulterers: Some Go to Take Part, Others Just to Watch," New York Times, November 3, 1996, www.nytimes.com/1996/11/03/world/stoning-of-afghan-adulterers-some-go-to-take-partothers-just-to-watch.html.

32 Ibid.

33 "Who Are the Taliban?" BBC, February 27, 2020, www.bbc.com/news/world-south-asia-11451718; Nicholas Wroe, "A Culture Muted," Guardian, October 13, 2001, www.theguardian.com/world/2001/oct/13/afghanistan. books; Matinuddin, The Taliban Phenomenon.

34 Barry Bearak, "Over World Protests, Taliban Are Destroying Ancient Buddhas," New York Times, March 10, 2001, www.nytimes.com/2001/03/04/world/over-world-protests-taliban-are-destroying-ancient-buddhas.html.

35 Amnesty International, Women in Afghanistan: The Violations Continue (London: Amnesty International, 1997).

36 Bahaar Joya, "Invisible Taliban Child Brides, Widows Trapped as Sex Slaves," Reuters, August 23, 2017, https:// fr.reuters.com/article/us-afghanistan-rights-women-idUSKCN1B31PL. 
37 M.J. Gohari, The Taliban (New York: Oxford University Press, 2000), 108-110.

38 Zaeff, My Life With the Taliban, 136-144; Fergusson, Taliban, 87.

39 James C. McKinley, Jr., "Bombings in East Africa," New York Times, August 8, 1998, www.nytimes.com/1998/08/08/ world/bombings-east-africa-overview-bombs-rip-apart-2-us-embassies-africa-scores.html.

40 James Bennet, “U.S. Fury on 2 Continents," New York Times, August 21, 1998, www.nytimes.com/1998/08/21/ world/us-fury-2-continents-overview-us-cruise-missiles-strike-sudan-afghan-targets.html.

41 UNSCR 1333, December 19, 2000, reinforced by UNSCR 1363, allowed for measures of counterterrorism. The Taliban vowed to kill any UN officials it found in either Afghanistan or Pakistan. See Rashid, Taliban, xi.

42 Sami Yousafzai and Ron Moreau, "The Taliban in Their Own Words," Newsweek, October 5, 2009.

43 Richard Norton-Taylor, “Taliban Hit by Bombs Used in Vietnam," Guardian, November 6, 2001, www.theguardian.com/world/2001/nov/07/afghanistan.terrorism6.

44 See, for example, Human Rights Watch, Fatally Flawed: Cluster Bombs and Their Use by the United States in Afghanistan (New York: Human Rights Watch, 2002).

45 James Dobbins, After the Taliban (Washington, DC: Potomac Books, 2008).

46 Olivier Roy, Islam and Resistance in Afghanistan (New York: Cambridge Middle East Library, 1986), 224.

47 Zaeff, My Life With the Taliban,

48 Antonio Giustozzi, Empires of Mud (London: Hurst, 2009).

49 Steven Erlanger, "Talks in Bonn End With Deal On Leadership For Afghans," New York Times, December 5, 2001, www.nytimes.com/2001/12/05/world/nation-challenged-negotiations-talks-bonn-end-with-deal-leadershipfor-afghans.html; Dobbins, After the Taliban.

50 Antonio Giustozzi, Koran, Kalashnikov and Laptop: The Neo-Taliban Insurgency in Afghanistan 2002-2007 (London: Hurst, 2007), 11-32.

51 Declan Walsh, “In Hiding, Bin Laden Had Four Children and Five Houses," New York Times, March 29, 2012, www.nytimes.com/2012/03/30/world/asia/on-run-bin-laden-had-4-children-and-5-houses-a-wife-says.html.

52 Ivan Arreguin-Toft, "The Country as a Whole: Imagined States and the Failure of COIN in Afghanistan," in War and State-Building in Afghanistan: Historical and Modern Perspectives, ed. Scott Gates and Kaushik Roy (New York: Bloomsbury, 2015), 220-221 and 236-237; Thomas Barfield, Afghanistan: A Cultural and Political History (Princeton: Princeton University Press, 2012), 274-275.

53 "NATO and Afghanistan," North Atlantic Treaty Organization, July 8, 2020, www.nato.int/cps/en/natohq/topics_8189.htm.

54 Sippi Azarbaijani-Moghaddam et al., Afghan Hearts, Afghan Minds (London: BAAG, 2008).

55 Arreguin-Toft, "The Country as a Whole," 236.

56 Rajiv Chandrasekaran, "US Military Dismayed by Delays in 3 Key Development Projects in Afghanistan," Washington Post, April 28, 2011, www.washingtonpost.com/world/us-military-dismayed-by-delays-in-3-key-development-projects-in-afghanistan/2011/04/22/AFD6jq8E_story.html.

57 Antonio Giustozzi and Mohammed Isaqzadeh, Policing Afghanistan: The Politics of the Lame Leviathan (London: Hurst, 2013).

58 Giustozzi, Koran, Kalashnikov and Laptop.

59 See, for example, Elizabeth Bumiller, “West Point Divided on a Doctrine's Fate," New York Times, May 27, 2012, www. nytimes.com/2012/05/28/world/at-west-point-asking-if-a-war-doctrine-was-worth-it.html?_r=1\&pagewanted=all.

60 "Tribal Security System (Arbakai) in Southeast Afghanistan," Government of the United Kingdom, January 1, 2008, www.gov.uk/research-for-development-outputs/tribal-security-system-arbakai-in-southeast-afghanistan.

61 Azarbaijani-Moghaddam et al., Afghan Hearts, Afghan Minds.

62 Michael Semple, Reconciliation in Afghanistan (Washington, DC: U.S. Institute for Peace, 2009).

63 Antonio Giustozzi, The Army of Afghanistan: A Political History of a Fragile Institution (London: Hurst, 2016).

64 Anthony Cordesman, The Ongoing Lessons of the Afghan and Iraq Wars (Washington, DC: Center for Strategic and International Studies, 2008); Anthony Cordesman, The Afghan War: Key Developments and Metrics (Washington, DC: Center for Strategic and International Studies, 2017).

65 Robert D. Crews and Tarzi Amin, The Taliban and the Crisis of Afghanistan (Cambridge, MA: Harvard University Press, 2008).

66 Giustozzi, Koran, Kalashnikov and Laptop.

67 Zaeff, My Life With the Taliban, 34; Fergusson, Taliban.

68 Yousafzai and Moreau, "The Taliban in Their Own Words."

69 Dawood Azami, “Afghanistan: How Does the Taliban Make Money?” BBC, December 22, 2018, www.bbc.com/ news/world-46554097.

70 Antonio Giustozzi, The Taliban at War, 2001-2018 (London: Hurst, 2019). Giustozzi, Empires of Mud, covers the contrasting tactics and approach of patronage by warlords. 
71 Office on Drugs and Crime, Afghanistan: Opium Survey 2015 (New York: United Nations, 2015).

72 Chris Johnson and Jolyon Leslie, Afghanistan: The Mirage of Peace (London: Zed Books, 2008), 130.

73 Giustozzi, Koran, Kalashnikov, and Laptop, 86; Giustozzi, The Taliban at War, 77-108.

74 Giustozzi, The Taliban at War, 77-108 and 197-236.

75 Don Rassler and Vahid Brown, The Haqqani Nexus and the Evolution of al-Qa ida (West Point: Combating Terrorism Center, 2011). For an example, see "Kabul: Gunmen Attack Intercontinental Hotel," BBC, January 2018, www. bbc.co.uk/news/world-asia-42761881.

76 See, for example, Carlotta Gall, “9 Americans Die in Afghan Attack," New York Times, July 14, 2008, www.nytimes. com/2008/07/14/world/asia/14afghan.html.

77 Peter Baker, "How Obama Came to Plan for 'Surge' in Afghanistan," New York Times, December 5, 2009, www. nytimes.com/2009/12/06/world/asia/06reconstruct.html.

78 “Afghanistan Surge Achieved Its Mission, Dempsey Says," The Nation, September 12, 2012, https://nation.com. pk/19-Sep-2012/afghanistan-surge-achieved-its-mission-dempsey-says; Doug Mataconis, "Was Obama’s 'Afghan Surge' A Failure?" Outside the Beltway (blog), August 26, 2012, www.outsidethebeltway.com/was-obamas-afghansurge-a-failure/; Victor Davis Hanson, "Iraq and Afghanistan: A Tale of Two Surges," CBS News, December 1, 2011, www.cbsnews.com/news/iraq-and-afghanistan-a-tale-of-two-surges/.

79 Stanley McChrystal, Commander's Initial Assessment (Kabul: NATO ISAF Headquarters, August 30, 2009), 1-2.

80 Scott Gates et al., "Continuity and Change in Asymmetric Warfare in Afghanistan: From the Mughals to the Americans," in War and State-Building in Afghanistan: Historical and Modern Perspectives, ed. Scott Gates and Kaushik Roy (New York: Bloomsbury, 2015), 35; Personal interviews, Oxford, names omitted, March 2012.

81 Thom Shanker, “At Odds With Air Force, Army Adds Its Own Aviation Unit," New York Times, June 22, 2008, www.nytimes.com/2008/06/22/washington/22military.html.

82 President Hamid Karzai, interview published in the New York Times, April 26, 2008.

83 Peter Beaumont, "Fear, Disillusion and Despair: Notes From a Divided Land as Peace Slips Away," Guardian, June 7, 2008, www.theguardian.com/world/2008/jun/08/afghanistan.

84 Giustozzi, The Army of Afghanistan; Antonio Giustozzi, “The Afghan National Army Unwarranted Hope?” RUSI Journal 154, no. 6 (2009): 36-42.

85 Anthony Cordesman, Afghan National Security Forces: Shaping the Path to Victory (Washington, DC: Center for Strategic and International Studies, 2009).

86 Anthony Davis, "Home-Grown Army: Afghan National Army," Jane's Defence Weekly, December 12, 2008.

87 Antonio Giustozzi, "Auxiliary Force or National Army? Afghanistan's 'ANA' and the Counterinsurgency Effort, 2002-2006," Small Wars and Insurgencies 18, no. 1 (2007): 45-67.

88 Mark Moyar, “Afghanistan and Leadership," Wall Street Journal, October 5, 2009, www.wsj.com/articles/SB10001 424052748703298004574454810540018326.

89 Anthony Cordesman, Winning in Afghanistan: Creating Effective Afghan Security Forces (Washington, DC: Center for Strategic and International Studies, January 2008).

90 Jan E. Haug, "The Operational Mentoring and Liaison Team Program as a Model for Assisting the Development of an Effective Afghan National Army" (master's thesis, U.S. Army Command and General Staff College, 2009).

91 Bill Roggio and Lisa Lundquist, "Green-on-Blue Attacks in Afghanistan: The Data," Long War Journal, June 17, 2017, www.longwarjournal.org/archives/2012/08/green-on-blue_attack.php.

92 Richard Andrade, "U.S. Pilots Advise, Assist Fledgling Afghan Air Corps," U.S. Army, September 30, 2010, www. army.mil/article/45886/u_s_pilots_advise_assist_fledging_afghan_air_corp.

93 Seth G. Jones, Counterinsurgency in Afghanistan (Santa Monica: RAND, 2008).

94 Rob Johnson, True to Their Salt: Indigenous Personnel in Western Armed Forces (New York: Oxford University Press), 337-371.

95 Roggio and Lundquist, "Green-on-Blue Attacks."

96 Office on Drugs and Crime, Afghanistan: Opium Winter Assessment (New York: United Nations, 2009); Amin Tarzi, "Afghanistan: Kabul Mulls Relations with Iran," RFE/RL, March 17, 2007, www.rferl.org/a/1075333. html; "Iran and Afghanistan," Institute for the Study of War, accessed October 15, 2020, www.understandingwar.org/ iran-and-afghanistan.

97 Richard Haass, “The Pakistan Conundrum,” Project Syndicate, January 12, 2018, www.project-syndicate.org/ commentary/united-state-pakistan-relations-aid-cutoff-by-richard-n-haass-2018-01.

98 Avinash Paliwal, My Enemy's Enemy: India in Afghanistan from the Soviet Invasion to the US Withdrawal (London: Hurst, 2017), 274-279.

99 “Osama bin Laden Killed in Pakistan,” Al Jazeera, May 2, 2011, www.aljazeera.com/news/2011/5/2/osama-binladen-killed-in-pakistan; "Pakistan PM Imran Khan Says Osama Bin Laden Was 'Martyred' When Killed During US Army Raid," London Evening Standard, June 26, 2020, www.standard.co.uk/news/world/osama-bin-ladenmartyred-pakistan-imran-khan-a4480806.html. 
100 Abdul Sayed and Colin P. Clarke, "The Islamic State in Afghanistan Is Down, but Not Out," RAND (blog), September 14, 2020, www.rand.org/blog/2020/09/the-islamic-state-in-afghanistan-is-down-but-not-out.html.

101 Emran Feroz and Abdul R. Lakanwal, "In Rural Afghanistan, Some Taliban Gingerly Welcome Girls Schools," Foreign Policy, May 4, 2020, https://foreignpolicy.com/2020/05/04/afghanistan-taliban-girls-schools/.

102 Farzad R. Bonesh, "Factors Affecting Divisions Among Afghan Taliban: Internal and External Forces Are Keeping the Taliban Split Into Two Factions," Asia Times, May 22, 2020, https://asiatimes.com/2020/05/ factors-affecting-divisions-among-afghan-taliban/.

103 Jeffrey A. Dressler, The Haqqani Network: From Pakistan to Afghanistan (Washington, DC: Institute for the Study of War, 2010).

104 Richard Haas, “How Not to Leave Afghanistan," Project Syndicate, March 3, 2020, www.project-syndicate.org/ commentary/trump-us-taliban-agreement-poor-prospects-by-richard-n-haass-2020-03?barrier=accesspaylog.

105 Sarah Dadouch et al., "U.S. Signs Peace Deal With Taliban Agreeing to Full Withdrawal of American Troops from Afghanistan," Washington Post, February 29, 2020, www.washingtonpost.com/world/asia_pacific/afghanistan-ustaliban-peace-deal-signing/2020/02/29/b952fb04-5a67-11ea-8efd-0f904bdd8057_story.html. 